\title{
Genotype $\times$ environment interaction of quality protein maize grain yield in Nepal
}

\author{
${ }^{1}$ Jiban Shrestha*, ${ }^{1}$ Chitra Bahadur Kunwar, ${ }^{1}$ Jharana Upadhyaya, \\ ${ }^{1}$ Maiya Giri, ${ }^{2}$ Ram Bahadur Katuwal, ${ }^{3}$ Ramesh Acharya, ${ }^{4}$ Suk Bahadur \\ Gurung, ${ }^{5}$ Bhim Nath Adhikari, ${ }^{6}$ Amrit Prasad Paudel, ${ }^{7}$ Ram Babu Paneru \\ ${ }^{1}$ National Maize Research Program, Rampur, Chitwan \\ ${ }^{2}$ ARS, Pakhribas, ${ }^{3}$ ABD, Khumaltar, ${ }^{4}$ HCRP, Kabre, \\ ${ }^{5}$ RARS, Doti, ${ }^{6}$ RARS, Lumle, ${ }^{7}$ ARS, Surkhet \\ *Corresponding author email: jibshrestha@gmail.com
}

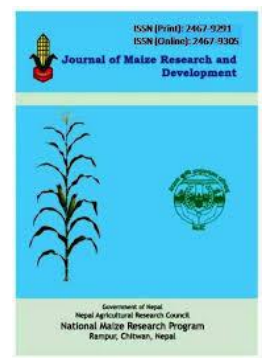

Received: September 2016; Revised: October 2016; Accepted: November 2016

\begin{abstract}
In order to determine $\mathrm{G} \times \mathrm{E}$ interaction of quality protein maize grain yield, six maize genotypes were evaluated under different environments of three Terai (Chitwan, Surkhet and Doti) and four mid hill (Dhankuta, Lalitpur, Dolakha and Kaski) districts of Nepal during summer seasons of 2014 and 2015. The experiments were conducted using randomized complete block design along with three replications. The genotypes namely S99TLYQ-B, S99TLYQ-HG-AB and S03TLYQ-AB-01 were identified high yielding and better adapted genotypes for Terai environments with grain yield of $4199 \mathrm{~kg} \mathrm{ha}^{-1}$, $3715 \mathrm{~kg} \mathrm{ha}^{-1}$, and $3336 \mathrm{~kg} \mathrm{ha}^{-1}$ respectively and S99TLYQ-B and S03TLYQ-AB-01 for mid hill environments with grain yield of $4547 \mathrm{~kg} \mathrm{ha}^{-1}$ and $4365 \mathrm{~kg} \mathrm{ha}^{-1}$ respectively. Therefore, these genotypes can be suggested for cultivation in their respective environments in the country.
\end{abstract}

Keywords: Evaluation, grain yield and quality protein maize

Correct citation: Shrestha, J., Kunwar, C.B., Upadhyaya, J., Giri, M., Katuwal, R.B., Acharya, R., Gurung, S.B., Adhikari, B.N., Paudel, A.P., \& Paneru, R.B. (2016).

Genotype $\times$ environment interaction of quality protein maize grain yield in Nepal.

Journal of Maize Research and Development, 2 (1): 66-73, doi: http://dx.doi.org/10.3126/jmrd.v2i1.16216

\section{INTRODUCTION}

The continuous evaluation and development of new varieties of maize is necessary to ensure food security in Nepal. In general, three types of hunger (calorie, protein, and micro nutrient deficiency) are facing by large portion of the people. Deployment of quality protein maize (QPM) is one of the good strategies to solve the problem of calorie and protein deficiency. In maize protein the most limiting amino acid are lycine and tryptophan (Kies et al., 1965). These amino acids are nearly double in QPM as compared to normal maize. FAO (1992) mentioned that about $80 \%$ is the 
biological value of QPM protein which is nearly double of normal maize. The QPM provides better quality feed and fodder to poultry, cattle and swine.

Maize has great diversity and is adaptive across various agro-ecological zones (Ferdu et al., 2002). Across the environments where the improved varieties are adapted would produce high and stable yields (CIMMYT, 1991). The preliminary step in varietal release is to evaluate the genotypes for yield potential and adaptation to the environments where it is cultivated. In most cases maize breeders look for a variety that has good mean performances over a large array of environments and years Gurmu et al. (2009). The continuous $\mathrm{G} \times \mathrm{E}$ study is necessary because with the changing environments, the performance of maize genotypes differs across the agro-ecologies. Under diverse agro ecologies in Nepal the information regarding the effect of genotype, environment and their interaction is not sufficient. Therefore, this study was done to evaluate the adaptability of six QPM maize genotypes in the Terai and Mid hill environments using AMMI model.

\section{MATERIALS AND METHODS}

\section{Description of locations}

These studies were conducted during summer seasons of 2014 and 2015 at 3 locations of terai and 4 locations of mid hill districts. The mid hill environments were Pakhribas (Dhankuta), Khumaltar (Lalitpur), Kabre (Dolakha) and Lumle (Kaski) and Terai environments were Bagyatada (Doti), Rampur (Chitwan), Madi (Chitwan) and Surkhet. The short description of these locations are given as below (Table 1).

Table 1. Description of experimental locations

\begin{tabular}{|c|c|c|c|c|}
\hline \multirow[t]{2}{*}{ Environments } & \multirow{2}{*}{$\begin{array}{l}\text { Altitude, (m) } \\
\text { (m.a.s.l) }\end{array}$} & \multirow{2}{*}{$\begin{array}{l}\text { Annual rainfall } \\
(\mathrm{mm})\end{array}$} & \multicolumn{2}{|c|}{ Global Position } \\
\hline & & & Longitude & Latitude \\
\hline \multicolumn{5}{|l|}{ Hills } \\
\hline Pakhribas (Dhankuta) & $1315-2025$ & $1500-1600$ & $87^{0} 17^{\prime} 61^{\prime} \mathrm{E}$ & $27^{0} 02^{\prime} 96^{\prime} \mathrm{N}$ \\
\hline Khumaltar(Lalitpur) & 1368 & & $85^{\circ} 20^{\prime} \mathrm{E}$ & $27^{0} 40^{\prime} \mathrm{N}$ \\
\hline Kabre (Dolakha) & $1600-1740$ & 2466.2 & $86^{0} 80^{\prime} \mathrm{E}$ & $27^{0} 38^{\prime} \mathrm{N}$ \\
\hline Lumle (Kaski) & 848 & 3172.85 & $83^{0} 58 ' 27.72 " \mathrm{E}$ & $28^{0} 13^{\prime} 6.8^{\prime \prime} \mathrm{N}$ \\
\hline \multicolumn{5}{|l|}{ Terai } \\
\hline Bagyatada (Doti) & 610 & $\begin{array}{l}\text { Not exceed } \\
1000\end{array}$ & $80^{0} 55^{\prime} \mathrm{E}$ & $29^{0} 15^{\prime} \mathrm{N}$ \\
\hline Rampur (Chitwan) & 228 & Over 1500 & $84^{0} 19^{\prime} \mathrm{E}$ & $27^{0} 40^{\prime} \mathrm{N}$ \\
\hline Madi (Chitwan) & 110 & 1500 & $84^{0} 43^{\prime} \mathrm{E}$ & $27^{0} 40^{\prime} \mathrm{N}$ \\
\hline Surkhet & 580 & 1550 & $81^{0} 47 " \mathrm{E}$ & $28^{0} 30^{\prime \prime} \mathrm{N}$ \\
\hline
\end{tabular}

\section{Genetic materials}

Six maize genotypes were evaluated in mid hills and Terai environments of Nepal during summer seasons of 2014 and 15. The genotypes were SO3TLYQ-AB-01, SOTLYQ-AB-02, S99TLYQ-HG-AB, S99TLYQ-B, Poshilo Makai-1 and Farmer's variety. Farmer's variety was Rampur Composite.

\section{Experimental design and cultural practices}

The experiments were carried out using randomized complete block design along with three replications. The individual plot was $13.5 \mathrm{~m}^{2}(4.5 \mathrm{~m} \times 3 \mathrm{~m})$. The spacing was 
$0.75 \mathrm{~m}$ for row to row and $0.25 \mathrm{~m}$ for plant to plant. Fertilizer was applied @ 120:60:40 $\mathrm{N}, \mathrm{P}_{2} \mathrm{O}_{5}, \mathrm{~K}_{2} \mathrm{O}$ kg ha ${ }^{-1}$. The full dose of $\mathrm{P}_{2} \mathrm{O}_{5}$ and $\mathrm{K}_{2} \mathrm{O}$ along with half of $\mathrm{N}$ were used as basal dose. The half of the $\mathrm{N}$ was used into two times; at knee-high and pretasseling/silking stages. Rest of agronomic practices was done as per recommendation of National Maize Research Program, Rampur, Chitwan, Nepal.

Table 2. Description of genotypes with their characteristics

\begin{tabular}{|c|c|c|c|c|}
\hline SN & Genotype & Parentage & Origin & General description \\
\hline 1 & $\begin{array}{l}\text { SO3TLYQ- } \\
\text { AB-01 }\end{array}$ & $\begin{array}{l}\text { Formed using } \\
\text { inbreds from } \\
\text { heterotic group A } \\
\text { and B }\end{array}$ & CIMMYT, Mexico & $\begin{array}{l}\text { This is open pollinated, prerelease and } \\
\text { yellow variety for Terai }\end{array}$ \\
\hline 2 & $\begin{array}{l}\text { SOTLYQ- } \\
\text { AB-02 }\end{array}$ & $\begin{array}{l}\text { Formed using } \\
\text { inbreds from } \\
\text { heterotic group A } \\
\text { and B }\end{array}$ & CIMMYT, Mexico & $\begin{array}{l}\text { This is open pollinated, prerelease } \\
\text { yellow variety for Terai }\end{array}$ \\
\hline 3 & S99TLYQ-B & $\begin{array}{l}\text { Formed using } \\
\text { inbreds derived } \\
\text { from heterotic } \\
\text { group B }\end{array}$ & CIMMYT, Mexico & $\begin{array}{l}\text { This genotype is open pollinated, } \\
\text { prerelease, yellow variety for terai and } \\
\text { mid hills }\end{array}$ \\
\hline 4 & $\begin{array}{l}\text { S99TLYQ- } \\
\text { HG-AB }\end{array}$ & $\begin{array}{l}\text { Formed using } \\
\text { inbreds from } \\
\text { heterotic group A } \\
\text { and B }\end{array}$ & CIMMYT, Mexico & $\begin{array}{l}\text { This is open pollinated, prerelease } \\
\text { yellow variety for Terai }\end{array}$ \\
\hline 5 & $\begin{array}{l}\text { Poshilo } \\
\text { Makai-1 }\end{array}$ & $\begin{array}{l}\text { Formed using } \\
\text { inbreds derived } \\
\text { from heterotic } \\
\text { group A and B }\end{array}$ & CIMMYT, Mexico & $\begin{array}{l}\text { This is open pollinated white variety } \\
\text { released in } 2008 \text {. It is recommended } \\
\text { for Terai and mid hills }\end{array}$ \\
\hline 6 & $\begin{array}{l}\text { Rampur } \\
\text { Composite } \\
\text { (Farmer's } \\
\text { Variety) }\end{array}$ & $\begin{array}{l}\text { Formed from } \\
\text { Thai composite- } 1 \\
\times \text { Suwan-1 }\end{array}$ & & $\begin{array}{l}\text { This is open pollinated, full season } \\
\text { yellow variety released in } 1975 \text {. It is } \\
\text { recommended for Terai and mid hills } \\
\text { regions of Nepal }\end{array}$ \\
\hline
\end{tabular}

(Source: Shrestha and Tripathi, 2014)

\section{Data recording}

Grain yields were adjusted to $80 \%$ shelling recovery. Grain yield was estimated using formula adopted by Carangal et al. (1971) and Shrestha et al. (2015) by adjusting the grain moisture at $15 \%$ and converted to the grain yield $\mathrm{kg}$ per hectare.

\section{Statistical analysis}

The combined ANOVA for all locations was done to estimate the variations in the genotypes under study and partitioning of $\mathrm{G} \times \mathrm{E}$ interaction. Data were analyzed through GENSTAT packages applying 5\% significance level. 


\section{RESULTS AND DISCUSSION}

The pooled analysis of genotypes over terai locations showed that the highest grain yield was given by S99TLYQ-B (4199 $\mathrm{kg} \mathrm{ha}^{-1}$ ) followed by S99TLYQ-HG-AB (3715 kg ha ${ }^{-1}$ ), S03TLYQ-AB-01 (3336 kg ha ${ }^{-1}$ ) excluding Farmer's Variety. The nonsignificant effects were found for genotypes, location and genotype $\times$ environment interaction (Table 3).

Table 3.Combined analysis of QPM genotypes for grain yield $\left(\mathrm{kg} \mathrm{ha}^{-1}\right)$ at Doti, Rampur, Madi and Surkhet during summer seasons of 2014 and 2015

\begin{tabular}{lllllll}
\hline SN & Genotypes & Doti & Rampur & Madi & Surkhet & Combined \\
\hline 1 & SO3TLYQ-AB-01 & $1258 \mathrm{c}$ & $2162 \mathrm{~b}$ & 4539 & $5080 \mathrm{~b}$ & 3336 \\
2 & SOTLYQ-AB-02 & $1467 \mathrm{c}$ & $3392 \mathrm{ab}$ & 4781 & $3956 \mathrm{ab}$ & 2937 \\
3 & S99TLYQ-B & $1572 \mathrm{bc}$ & $3241 \mathrm{ab}$ & 5737 & $3383 \mathrm{ab}$ & 4199 \\
4 & S99TLYQ-HG-AB & $1664 \mathrm{bc}$ & $2959 \mathrm{ab}$ & 4014 & $4182 \mathrm{ab}$ & 3715 \\
5 & Poshilo Makai-1 & $1979 \mathrm{~b}$ & $3390 \mathrm{ab}$ & 4594 & $1905 \mathrm{a}$ & 3250 \\
6 & Farmer's Variety & $2563 \mathrm{a}$ & $4167 \mathrm{a}$ & 4053 & $3967 \mathrm{ab}$ & 4490 \\
& F-test & $* *$ & $*$ & $\mathrm{~ns}$ & $*$ & 0.577 \\
& Env & & & & & 0.062 \\
& Gen $\times$ Env & & & & & 0.926 \\
& CV,\% & 13.2 & 30 & 20.30 & 30.38 & 31.96 \\
& LSD0.05 & 421.9 & 1756.3 & 2122.2 & 2574.6 & $4996(\mathrm{loc} \times$ gen $)$ \\
\hline
\end{tabular}

The genotypes being close to each other produce similar response and those close to environment indicate their better adaptation to that particular environment. SO3TLYQAB-01 and S99TLYQ-B showed similar performance for grain yield. The genotypes Poshilo Makai-1 and Farmer's Variety were similar in their grain yield performance and they were suitable for Doti and Rampur where as SO3TLYQ-AB-01 and S99TLYQ-B were suitable for Surkhet environment (Figure 1). This finding was very similar to findings of Anley et al. (2013).

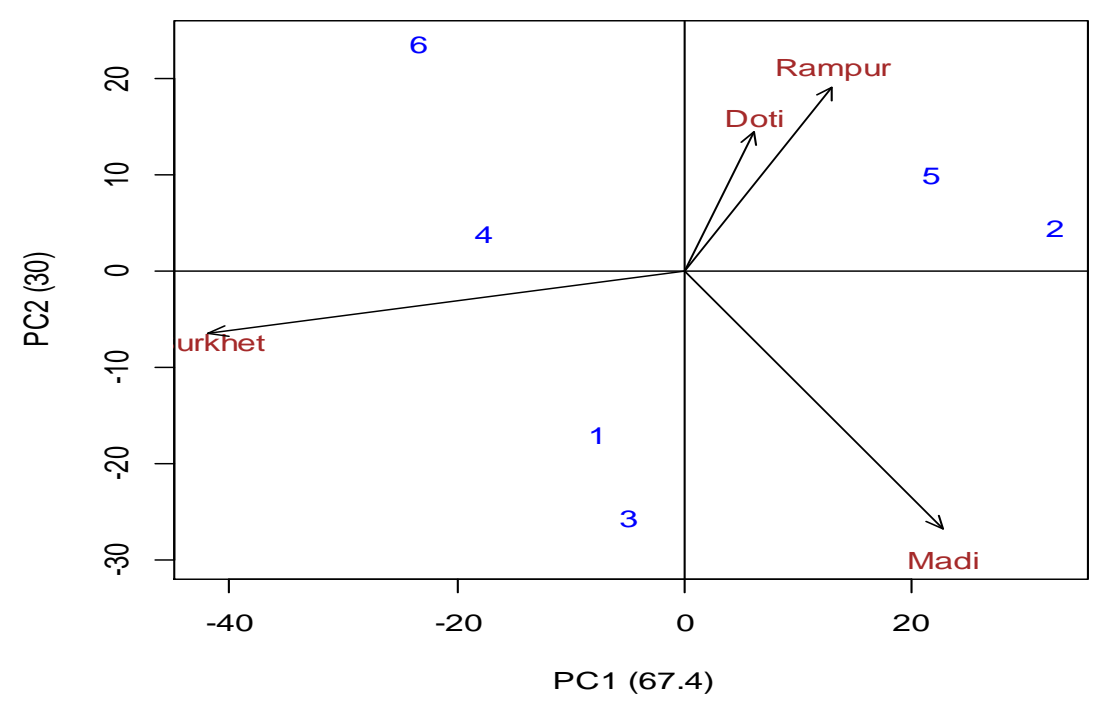

Figure 1.Stability of QPM genotypes across the tested Terai locations (Doti, Rampur, Madi and Surkhet) during summer seasons of 2014 and 2015. 
The combined analysis of variance for grain yield (Table 4) revealed that there was non significant interaction for replication within environment. Similarly non significant effect for genotype and genotype $\times$ environment interaction and highly significant effect for environment were observed. This clearly showed that effect of environment had more influential effect on grain yield.

Table 4. Analysis of variance derived from AMMI analysis across the terai locations

\begin{tabular}{llllll}
\hline Source & DF & SS & MSS & F value & $\operatorname{Pr}(>\mathrm{F})$ \\
\hline ENV & 3 & 34162654 & 11387551 & 607000 & $0.000943 * * *$ \\
REP(ENV) & 1 & 19 & 19 & 0.000 & 0.997749 \\
GEN & 5 & 8889211 & 1777842 & 0.834 & 0.57668 \\
ENV:GEN & 15 & 12576434 & 838429 & 0.393 & 0.926219 \\
Error & 5 & 10662756 & 2132551 & & \\
\hline
\end{tabular}

Significance Codes: '***’ $0.001^{\text {‘**’ }} 0.01^{\text {'*’’ }} 0.05$

Across the mid hill locations pooled analysis of genotypes (Table 5) showed that the highest grain yield was given by S99TLYQ-B (4547 kg ha-1) followed by S03TLYQAB-01 (4365 kg ha ${ }^{-1}$ ) excluding Posilo Makai-1 and Farmer's Variety. The genotypes were significant. There was significant effect for genotype $\times$ location for grain yield. This finding was similar to findings of Carson et al. (2002). The significantly different $\mathrm{G} \times \mathrm{E}$ interactions was recorded for grain yield in maize (Makumbi, 2005; Menkir \& Ayodele, 2005).

Table 5. Combined analysis of QPM genotypes for grain yield $\left(\mathrm{kg} \mathrm{ha}^{-1}\right)$ at Pakhribas, Khumaltar, Kabre and Lumle during summer seasons of 2014 and 2015.

\begin{tabular}{lllllll} 
SN & Genotypes & \multicolumn{2}{l}{ Pakhribas Khumaltar } & Kabre & Lumle & Combined \\
\hline 1 & SO3TLYQ-AB-01 & 4441 & $2979 \mathrm{ab}$ & $3101 \mathrm{c}$ & $5594 \mathrm{~d}$ & 4365 \\
2 & SOTLYQ-AB-02 & 3866 & $1987 \mathrm{~b}$ & $2305 \mathrm{c}$ & $6013 \mathrm{~cd}$ & 4026 \\
3 & S99TLYQ-B & 4569 & $2927 \mathrm{ab}$ & $4683 \mathrm{c}$ & $4975 \mathrm{ab}$ & 4547 \\
4 & S99TLYQ-HG-AB & 4208 & $3304 \mathrm{ab}$ & $2343 \mathrm{~b}$ & $4669 \mathrm{abc}$ & 3847 \\
5 & Poshilo Makai-1 & 5454 & $3989 \mathrm{a}$ & $5629 \mathrm{ab}$ & $5482 \mathrm{ab}$ & 5340 \\
6 & Farmers Variety & 4196 & $3980 \mathrm{a}$ & $6389 \mathrm{a}$ & $3865 \mathrm{a}$ & 4549 \\
& F-test & $\mathrm{ns}$ & $*$ & $* *$ & $* *$ & 0.032 \\
& Env & & & & & $<0.001$ \\
& Gen $\times$ Env & & & & & 0.011 \\
& CV\% & 26.9 & 23.7 & 10.8 & 8.8 & 20.71 \\
& LSD & 2176.8 & 1378.5 & 1189.4 & 820.3 & 1950 (env x gen) \\
\hline
\end{tabular}

The Figure 2 indicated that the performance of SO3TLYQ-AB-01 seemed better for Pakhribas. Similarly, SOTLYQ-AB-02 was better for Lumle and Poshilo Makai-1 and S99TLYQ-B for Kabre condition. In hill environments the genotype by environment interaction for grain yield was highly significant this may be due to differences among the sites in soil fertility, relative humidity and temperature, all factors which affect performance. The results showed that the genotypes responded differently to different environmental conditions. Similar findings were observed by Butron et al. (2002). Ogunbodede et al. (2001) reported that the genotypes should be partially released for locations where the performance was most favorable. 


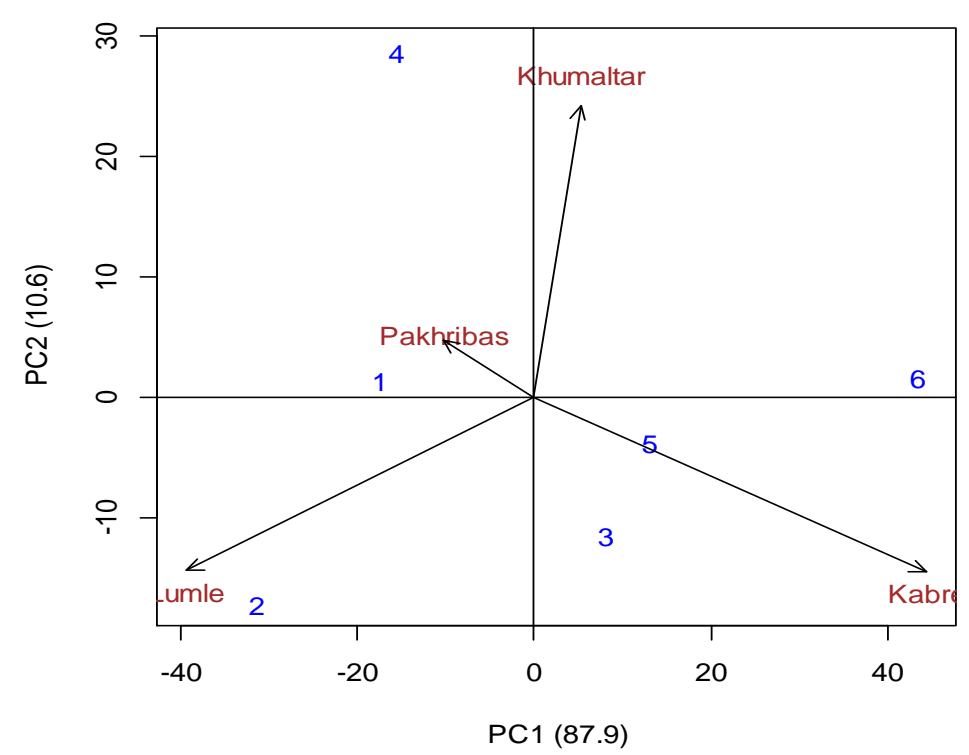

Figure 2. Stability of QPM genotypes across the hills locations. (Pakhribas, Khumaltar, Kabre and Lumle) during summer seasons of 2014 and 2015.

The combined analysis of variance for grain yield (Table 6) revealed non significant effect for replication within environment. For grain yield the effect of genotype was significant, genotype $\times$ environment effect was highly significant and environment was significant.

Table 6. Analysis of variance derived from AMMI analysis across mid hill locations

\begin{tabular}{llllll}
\hline Source & DF & SS & MSS & F value & $\operatorname{Pr}(>\mathrm{F})$ \\
\hline ENV & 3 & 18749637 & 6249879 & 3.495 & 0.10576 \\
REP(ENV) & 5 & 8941208 & 1788242 & 2.5662 & 0.05253 \\
GEN & 5 & 12247819 & 2449564 & 3.5152 & $0.015257^{*}$ \\
ENV:GEN & 15 & 34329473 & 2288632 & 3.2843 & $0.004211^{* *}$ \\
Error & 25 & 17421184 & 696847 & & \\
\hline
\end{tabular}

\section{CONCLUSION}

The better genotypes with respect to grain yield and location were Poshilo Makai1 and Farmer's Variety for Doti and Rampur where as SO3TLYQ-AB-01 and S99TLYQB for Surkhet. Similarly SO3TLYQ-AB-01 was better for Pakhribas, SOTLYQ-AB-02 for Lumle and Poshilo Makai-1 and S99TLYQ-B for Kabre condition. Therefore these varieties with respect to their specific adaptation can be recommended for general cultivation. 


\section{ACKNOWLEDGEMENTS}

The authors were grateful to National Maize Research Program, Rampur, Chitwan for financial and technical support. They were thankful to collaborative staffs from RARS Doti, ARS Pakhribas, ARS Surkhet, RARS Lumle, ADB Khumaltar and HCRP Kabre for their cooperation in the implementation of project activities. The authors acknowledged all the participating farmers for cultivating maize in the field trials.

\section{REFERENCES}

Anley, W., Zeleke, H., \& Dessalegn, Y. (2013). Genotype $\times$ Environment Interaction of Maize (Zea mays L.) across North Western Ethiopia. Journal of Plant Breeding and Crop Science , 5(9), 171-181.

Butron, A., Widstrom, N., Snook, M., \& Wiseman, B. (2002). Recurrent selection for corn earworm (Lepidoptera: Noctuidae) resistance in three closely related corn southern synthetics. Journal of Economic Entomology, 95, 458-462.

Carson, M.L., Goodman, M.M., \& Williamson, S.M. (2002). Variation in aggressiveness among isolates of Cercospora from maize as a potential cause of genotypeenvironment interaction in gray leaf spot trials. Plant Disease, 86, 1089-1093. http://dx.doi.org/10.1094/PDIS.2002.86.10.1089

Carangal, V.R., Ali, S.M., Koble, A.F., \& Rinke, E.H. (1971). Comparison of S1 with testcross evaluation for recurrent selection in maize. Crop Science, 11, 658-661.

CIMMYT. (1991). High Yielding Varieties Do Not Necessary Yield Less Under Unfavorable Conditions. CIMMYT Annual Report 1990. Mexico DF.

FAO. (1992). Maize in human nutrition. FAO Journal of Nutrition, 110, 1070-1074.

Ferdu, A., Demissew, K., \& Birhane, A. (2002). Major Insect Pests of Maize and their Management: A Review in: Nigussie M., D. Tanner and A.S. Twumasi (Eds.) Enhancing the Contribution of Maize to Food Security in Ethiopia. Proceeding of Second National Maize Workshop, Addis Ababa Ethiopia, 12- 16 Nov. 2001.

Gurmu, F., Mohammed, H., \& Mewmaw, G. (2009).Genotype x Environment Interactions and Stability of Soybean for grain yield and Nutrition quality. African Crop Science Journal, 17(2), 87 - 97.

Kies, C., Williams, E.R., \& Fox, H.M. (1965). Determination of first-limiting nitrogenous factors in corn protein for nitrogen retention in human adults. Journal of Nutrition. 86 (65), 350-356.

Makumbi, D. (2005). Phenotypic and genotypic characterization of white maize inbreds, hybrids and synthetics under stress and non-stress environments. $\mathrm{PhD}$ dissertation Submitted to the Office of Graduate Studies of Texas A and M University.

Menkir, A., \& Ayodele, M.A. (2005). Registration of 20 Tropical Mid-altitude Maize Line Sources with Resistance to Gray Leaf Spot. Crop Science, 45, 803-804. http://dx.doi.org/10.2135/cropsci2005.0803

Ogunbodede, B.A., Ajibade, S.R., \& Olakojo, S.A. (2001). Grain yield stability of new maize varieties in Nigeria: African Crop Science Journal, 9(4), 685-691.

Shrestha, J., Koirala, K., Katuwal, R., Dhami, N., Pokhrel, B., Ghimire, B., Prasai, H., Paudel, A., Pokhrel, K., \& KC, G. (2015). Performance evaluation of quality protein maize genotypes across various maize production agro ecologies of Nepal. Journal of Maize Research and Development, 1(1),21-27. doi: http://dx.doi.org/10.3126/jmrd.v1i1.14241 
Shrestha, J., Koirala, K., Katuwal, R., Dhami, N., Pokhrel, B., Ghimire, B., Prasai, H., Paudel, A., Pokhrel, K., \& KC, G. (2015). Performance evaluation of quality protein maize genotypes across various maize production agro ecologies of Nepal. Journal of Maize Research and Development, 1(1), 21-27. doi:http://dx.doi.org/10.3126/jmrd.v1i1.14241 